Article

\title{
Aluminum(III) triflate-catalyzed selective oxidation of glycerol to formic acid with hydrogen peroxide
}

\author{
Kang Kong, Difan Li, Wenbao Ma, Qingqing Zhou, Guoping Tang, Zhenshan Hou * \\ Key Laboratory for Advanced Materials, Research Institute of Industrial Catalysis, School of Chemistry and Molecular Engineering, East China University \\ of Science and Technology, Shanghai 200237, China
}

\section{A R T I C L E I N F}

\section{Article history:}

Received 10 November 2018

Accepted 25 January 2019

Published 5 April 2019

\section{Keywords:}

Aluminum(III) triflate

Glycerol

Hydrogen peroxide

Selective oxidation

Formic acid

\begin{abstract}
A B S T R A C T
Glycerol is a by-product of biodiesel production and is an important readily available platform chemical. Valorization of glycerol into value-added chemicals has gained immense attention. Herein, we carried out the conversion of glycerol to formic acid and glycolic acid using $\mathrm{H}_{2} \mathrm{O}_{2}$ as an oxidant and metal (III) triflate-based catalytic systems. Aluminum(III) triflate was found to be the most efficient catalyst for the selective oxidation of glycerol to formic acid. A correlation between the catalytic activity of the metal cations and their hydrolysis constants $\left(K_{\mathrm{h}}\right)$ and water exchange rate constants was observed. At $70{ }^{\circ} \mathrm{C}$, a formic acid yield of up to $72 \%$ could be attained within $12 \mathrm{~h}$. The catalyst could be recycled at least five times with a high conversion rate, and hence can also be used for the selective oxidation of other biomass platform molecules. Reaction kinetics and ${ }^{1} \mathrm{H}$ NMR studies showed that the oxidation of glycerol (to formic acid) involved glycerol hydrolysis pathways with glyceric acid and glycolic acid as the main intermediate products. Both the $\left[\mathrm{Al}(\mathrm{OH})_{x}\right]^{n+}$ Lewis acid species and $\mathrm{CF}_{3} \mathrm{SO}_{3} \mathrm{H}$ Brønsted acid, which were generated by the in-situ hydrolysis of $\mathrm{Al}(\mathrm{OTf})_{3}$, were responsible for glycerol conversion. The easy availability, high efficiency, and good recyclability of $\mathrm{Al}(\mathrm{OTf})_{3}$ render it suitable for the selective oxidation of glycerol to high value-added products.

(C) 2019, Dalian Institute of Chemical Physics, Chinese Academy of Sciences. Published by Elsevier B.V. All rights reserved.
\end{abstract}

\section{Introduction}

The catalytic conversion of biomass and its derivatives to various chemicals has been extensively studied over the past few decades to meet the increasing demands of the chemical industry $[1,2]$. Biodiesel, which is derived from the transesterification of animal fats and vegetable oils with methanol, has gained immense attention because of its environmental friendliness and recyclability. However, in the biodiesel manufacture process, a large amount of glycerol (GLY) is produced as a by-product. Utilization of excess GLY to promote the normal operation of the biodiesel industry chain is a major challenge
$[3,4]$. In order to achieve environmentally friendly and cost-effective biodiesel manufacture, efforts are being made to catalytically transform crude GLY into high value-added fine chemicals.

Because GLY consists of primary and secondary hydroxyl functional groups, various chemical derivatives can be obtained from it via various chemical reactions. Recently, it has been found that GLY can be deep-processed via various chemical approaches such as [5,6]: (1) esterification to GLY carbonates; (2) etherification to oxygenated fuel additives; (3) polymerization; (4) hydrogenation to produce 1,3-propanediol, 1,2-propanediol, and other raw materials for producing un-

\footnotetext{
* Corresponding author. Tel/Fax: +86-21-64251686; E-mail: houzhenshan@ecust.edu.cn

The authors are grateful for support from the National Natural Science Foundation of China $(21773061,21373082)$, and the Innovation Program of Shanghai Municipal Education Commission (15ZZ031).

DOI: S1872-2067(19)63319-X | http://www.sciencedirect.com/science/journal/18722067 | Chin. J. Catal., Vol. 40, No. 4, April 2019
} 
saturated polyester; and (5) oxidation to valuable oxygenated derivatives. Among these approaches, selective catalytic oxidation $[7,8]$ can yield a variety of oxygen-containing valuable chemicals such as 1,3-dihydroxyacetone, glyceraldehyde, lactic acid, propanol diacid, hydroxypyruvate, glycolic acid (GCA), formic acid (FA), and glyceric acid (GA). Many of these chemicals are important chemical reaction intermediates, which can further undergo a series of complex oxidation processes. However, such processes may lead to low product yields and high losses. Selective oxidation of GLY is challenging. This challenge can be overcome by obtaining a terminal product. Such a product can promote the selective oxidation of GLY for example to FA [9], which is an important chemical raw material widely used in the tanning, pharmaceutical, pesticide, textile printing and dyeing, agriculture, papermaking, and chemical industries [10]. Owing to the vast applications of FA in hydrogen storage and fuel cells, the need for its efficient production has increased significantly over the past few years. Since it can be easily transformed into carbon monoxide, FA is a convenient source of C1 raw material for the chemical industry [11]. Although the traditional methods for producing FA offer a high yield, they cause significant environmental pollution and utilize non-renewable raw materials. This limits the efficient and sustainable production of FA [12]. As a result, catalytic oxidation of GLY to FA via a facile and green route will not only solve the problem of inefficient utilization of excess GLY and promote the utilization of biodiesel, but will also provide an environmentally friendly approach to produce FA [13].

Over the past few years, several catalytic systems have been employed for the oxidation of GLY into organic carboxylic acids. Catalysts accelerate GLY oxidation while preventing the further oxidation of the intermediate products to $\mathrm{CO}_{2}$. Previous studies have shown that the GLY conversion activity of a catalyst is strongly related to its acidity. For example, GLY interacts differently with Lewis acid (L acid) and Brønsted acid (B acid) sites and dehydration reactions occur via different pathways, which depend on the concentration of the two acidic sites [14]. The oxidation of GLY to FA can be promoted significantly by carrying out acid-hydrolysis using inorganic acids (B acids) as additives (such as $\mathrm{H}_{2} \mathrm{SO}_{4}, \mathrm{HCl}$, and $\mathrm{H}_{3} \mathrm{SiW}_{12} \mathrm{O}_{4}$ ) [9,15-17]. Besides, the assembly of highly dispersed $\mathrm{Cu}$ nanoclusters anchored on nanocrystalline $\mathrm{SiO}_{2}-\mathrm{MnO}_{2}$ has been employed as a bifunctional catalyst for one-step conversion of GLY to acrylic acid using hydrogen peroxide, where $\mathrm{SiO}_{2}$ and hexagonal $\mathrm{MnO}_{2}$ sites act as acid sites for the dehydration reaction (GLY to acrolein), while $\mathrm{Cu}^{+}$sites are responsible for the oxidation reaction [18]. Furthermore, polyoxometalates $\mathrm{MPMo}_{12} \mathrm{O}_{40}\left(\mathrm{M}=\mathrm{Al}^{3+}\right.$ or $\mathrm{Cr}^{3+}$ ) (with $\mathrm{PMo}_{12} \mathrm{O}_{40}$ as the redox center) coupled with $\mathrm{L}$ acid sites $\mathrm{Al}^{3+}$ or $\mathrm{Cr}^{3+}$ have been found to be highly efficient for the production of lactate acid from GLY [19]. The correlation between B and L acid sites is favorable for GLY conversion [20-22].

Homogeneous $\mathrm{L}$ acid catalysts such as $\mathrm{AlCl}_{3}, \mathrm{BF}_{3}$, and $\mathrm{SnCl}_{4}$ normally decompose or deactivate when they are used in aqueous solutions. In contrast, metal triflates $\left(\left[\mathrm{M}\left(\mathrm{CF}_{3} \mathrm{SO}_{3}\right)_{x}\right], \mathrm{M}\right.$ $=$ metal center, $\left.\mathrm{CF}_{3} \mathrm{SO}_{3^{-}}=-{ }^{-} \mathrm{OTf}\right)$ such as $\mathrm{Bi}(\mathrm{OTf})_{3}, \mathrm{Ag}(\mathrm{OTf})$, In(OTf) 3 , and $\mathrm{Al}(\mathrm{OTf})_{3}$ are well-known for being active towards various reactions in water [23,24]. Although some metal triflates exhibit a high catalytic activity towards the selective oxidation of sulfides, methyl levulinate, and secondary alcohols with hydrogen peroxide [25-27], their oxidation activity towards biopolyols needs to be investigated. Based on our previous work on GLY oxidation using a silica-encapsulated heteropolyacid catalyst, in this work, we used $\mathrm{Al}(\mathrm{OTf})_{3}$, which is cheap, safe, and readily available as a catalyst to directly obtain FA from GLY under mild reaction conditions. Variations in the reaction parameters (temperature, $\mathrm{H}_{2} \mathrm{O}_{2} / \mathrm{GLY}$ molar ratio, and GLY dosage) were investigated in detail. A plausible reaction pathway for FA production by GLY oxidation was proposed on the basis of the activity test and ${ }^{1} \mathrm{H}$ NMR results. Moreover, it was found that this catalytic system can also be used for the oxidation of other biopolyols. Hence, we proposed a green and potential approach for FA production from biomass-derived polyols.

\section{Experimental}

\subsection{General remarks}

All the chemicals and solvents were commercially available and were used as received. Metal triflates $\mathrm{Al}(\mathrm{OTf})_{3}(\geq 98 \mathrm{wt} \%)$, $\mathrm{Bi}(\mathrm{OTf})_{3}(\geq 98 \mathrm{wt} \%), \operatorname{Ag}(\mathrm{OTf})(\geq 98 \mathrm{wt} \%)$, and $\mathrm{Zn}(\mathrm{OTf})_{2}(\geq 98$ wt $\%)$ were purchased from Sinopharm Chemical Reagent Co., Ltd., Shanghai. Ce(OTf) 3 ( $\geq 98 w t \%$ ) and Y(OTf)3 ( $\geq 98 w t \%)$ were purchased from J\&K Chemical. Sc(OTf) 3 ( $\geq 95 \mathrm{wt} \%)$ was purchased from Bidepharm. In(OTf) 3 ( $\geq 98 \mathrm{wt} \%$ ) was purchased from Aladdin Reagent. FA, GCA, acetic acid (AA), and GA were provided by Shanghai McLean Biochemical Technology. Hydrogen peroxide (30\%) was obtained from Sinopharm Chemical Reagent Co. Ltd. NMR spectra were recorded on a Bruker Advance III 400 instrument ( $500 \mathrm{MHz}$ for ${ }^{1} \mathrm{H}$ ) by using $\mathrm{d}_{6}$-DMSO as the solvent and TMS as the reference. Chemical shifts are given in parts per million. FT-IR spectra were recorded at room temperature on a Magna 550 (Nicolet, USA) FT-IR spectrometer. Inductively coupled plasma atomic emission spectroscopy (ICP-AES) analysis of (Al and S contents) of the catalysts was carried out on a Vanan 710 instrument.

\subsection{Catalytic production of FA from $G L Y$}

GLY oxidation reaction was carried out in a glass reactor $(25$

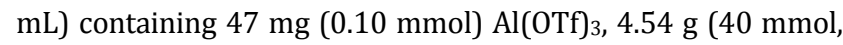
$30 \mathrm{wt} \%) \mathrm{H}_{2} \mathrm{O}_{2}, 0.37 \mathrm{~g}$ ( $4 \mathrm{mmol}$ ) GLY, and $2.37 \mathrm{~g}$ acetonitrile. The reaction mixture was stirred and heated at $70{ }^{\circ} \mathrm{C}$ for $12 \mathrm{~h}$. Similar procedure was employed for all the other metal salts and biomass platform molecules. Unless otherwise specified, the reaction was carried out at $70{ }^{\circ} \mathrm{C}$ for $12 \mathrm{~h}$ at a GLY/catalyst molar ratio of 40 . The reaction was quenched by placing the bottle into an ice cool water bath. The liquid products along with the unreacted substrate were collected and quantitatively analyzed on an Agilent 1260 high-performance liquid chromatograph equipped with a refractive index and ultraviolet $(210 \mathrm{~nm})$ detectors in series using a Bio-Rad Aminex HPX-87H column for product separation and diluted $\mathrm{H}_{2} \mathrm{SO}_{4}(0.5 \mathrm{Mm})$ as 
the eluent at $55^{\circ} \mathrm{C}$ and a flow rate of $0.5 \mathrm{~mL} / \mathrm{min}$. Prior to the analysis, the reaction mixture was filtered using a $0.22-\mathrm{mm}$ membrane filter. For catalyst recycling, the aqueous mixture was extracted thrice with dichloromethane, followed by drying under vacuum. All the experiments were carried out in duplicate and the average data were recorded.

The GLY conversion and product yields of the catalysts were calculated as follows:

Conversion $=G L Y$ converted $($ mole $) /$ total GLY in the feed $($ mole $) \times 100 \%$, Yield $=($ a product $($ mole $) /$ total GLY converted $($ mole $)) \times($ number of carbon atoms in the products $/ 3) \times 100 \%$, Carbon balance yield in liquid products $=$ Carbon atoms found in the liquid products/Carbon atoms of $G L Y \times 100 \%$.

\section{Results and discussion}

Metal salts of trifluoromethanesulfonic acid $\left(\mathrm{CF}_{3} \mathrm{SO}_{3} \mathrm{H}\right)$ act as potential catalysts for efficient sulfide oxidation in the presence of $\mathrm{H}_{2} \mathrm{O}_{2}$ [25]. The charge delocalization of the triflate group, $\mathrm{CF}_{3} \mathrm{SO}_{3}-$, confers a strong catalytic power to the metal salt by enhancing the cationic character of the metal induced by the low ion coordination capacity of the triflate anion [28]. However, the oxidation of biopolyols using metal triflates has rarely been reported [29]. In this work, we screened various metal triflates for catalytic oxidation of GLY and evaluated their catalytic performance. The oxidation reaction was carried out at $70^{\circ} \mathrm{C}$ for $12 \mathrm{~h}$ with a fixed amount of metal cation loading. As can be seen from Table 1, no product was detected in the absence of the catalyst or oxidant, indicating that the oxidation of GLY was catalyzed (Table 1, entries 1 and 10). We examined the catalytic efficiency of a series of commercially available metal triflates towards GLY oxidation. Among these metal triflate catalysts, $\mathrm{Bi}(\mathrm{OTf})_{3}, \mathrm{Ce}(\mathrm{OTf})_{3}$, and $\mathrm{Zn}(\mathrm{OTf})_{2}$ showed almost no activity for GLY oxidation (Table 1, entries 2-4). Moreover,
$\mathrm{Ag}(\mathrm{OTf}), \mathrm{Y}(\mathrm{OTf})_{3}$, and $\operatorname{In}(\mathrm{OTf})_{3}$ also showed very poor activity under the same mild reaction conditions, although trace amounts of GCA and AA could be detected in these cases (Table 1 , entries 5-7). Compared to these metal triflates, Sc(OTf) 3 showed a better catalytic activity with an FA yield of $41.5 \%$ and a GLY conversion of $71.7 \%$ (Table 1, entry 8). Interestingly, $\mathrm{Al}(\mathrm{OTf})_{3}$ exhibited excellent catalytic performance for GLY transformation with $72 \%$ FA yield and $100 \%$ GLY conversion (Table 1, entry 9). The FA yield obtained with this catalyst was close to that obtained in our previous study using a silica-encapsulated heteropolyacid catalytic system [30]. However, $\mathrm{Al}(\mathrm{OTf})_{3}$ offered the advantages of easy availability, simple manufacturing, low cost, and high efficiency.

These results indicate that the catalytic performance of these metal triflates strongly depends on their metal cation species (Table 1). This gives us further speculation whether the hydrolysis of different cations in aqueous hydrogen peroxide causes this difference in the activity of these metal triflates. Indeed, different metal triflates can be hydrolyzed to different degrees in aqueous solutions or in a mixed solution of water and organic solvents. The catalytic activity of metal triflates can be correlated with their hydrolysis constant $K_{\mathrm{h}}$ (Table 1). A lower $\mathrm{p} K_{\mathrm{h}}$ value implies a stronger hydrolysis tendency of the metal salt [31-33]. When the $\mathrm{p} K_{\mathrm{h}}$ values are large, the cations are generally difficult to hydrolyze. Nevertheless, if the $\mathrm{p} K_{\mathrm{h}}$ value of a cation is less than 4.3 , it can be easily hydrolyzed. As such, $\mathrm{Al}(\mathrm{OTf})_{3}$ with the lowest $\mathrm{p} K \mathrm{~h}$ value (1.14) showed the highest activity for GLY oxidation after Bi(OTf)3 (Table 1, entries 2 and 9). This indicates that $\mathrm{CH}_{3} \mathrm{SO}_{3} \mathrm{H}$, which was obtained as a hydrolysis product, significantly affected the reaction activity of $\mathrm{Al}(\mathrm{OTf})_{3}$. Although $\mathrm{Bi}(\mathrm{OTf})_{3}$ has a very low $\mathrm{p} K_{\mathrm{h}}$ (1.09), it showed no catalytic activity under the reaction conditions used in this study (Table 1, entry 2). The hydrolysis reaction of $\mathrm{Bi}(\mathrm{OTf})_{3}$ in the mixed solution of $\mathrm{CH}_{3} \mathrm{CN}$ and $\mathrm{H}_{2} \mathrm{O}_{2}$ occurred

Table 1

Oxidation of GLY with different metal triflate catalysts ${ }^{\text {a. }}$

\begin{tabular}{|c|c|c|c|c|c|c|c|}
\hline \multirow{2}{*}{ Entry } & \multirow{2}{*}{ Catalyst } & \multirow{2}{*}{$\mathrm{p} K_{\mathrm{h}}{ }^{\mathrm{b}}$} & \multirow{2}{*}{ WERC } & \multirow{2}{*}{ Conversion (\%) } & \multicolumn{3}{|c|}{ Yield (\%) } \\
\hline & & & & & FA & GCA & AA \\
\hline 1 & none & - & - & 0.0 & 0.0 & 0.0 & 0.0 \\
\hline 2 & $\operatorname{Bi}(\mathrm{OTf})_{3}$ & 1.09 & - & 0.0 & 0.0 & 0.0 & 0.0 \\
\hline 3 & $\mathrm{Ce}(\mathrm{OTf})_{3}$ & 8.3 & $2.7 \times 10^{8}$ & 0.0 & 0.0 & 0.0 & 0.0 \\
\hline 4 & $\mathrm{Zn}(\mathrm{OTf})_{2}$ & 8.96 & $5.0 \times 10^{8}$ & 4.0 & 0.0 & 0.0 & 4.0 \\
\hline 5 & $\mathrm{Ag}(\mathrm{OTf})$ & 12 & $>5.0 \times 10^{6}$ & 12.3 & 0.0 & 0.7 & 0.0 \\
\hline 6 & $\mathrm{Y}(\mathrm{OTf})_{3}$ & 7.7 & $1.3 \times 10^{7}$ & 18.2 & 0.0 & 16.0 & 0.0 \\
\hline 7 & $\operatorname{In}(\mathrm{OTf})_{3}$ & 4.0 & $4.0 \times 10^{4}$ & 11.5 & 0.0 & 0.0 & 7.2 \\
\hline 8 & $\mathrm{Sc}(\mathrm{OTf})_{3}$ & 4.3 & $4.8 \times 10^{7}$ & 71.7 & 41.5 & 12.5 & 2.2 \\
\hline 9 & $\operatorname{Al}(\mathrm{OTf})_{3}$ & 1.14 & 1.6 & 100.0 & 72.0 & 20.0 & 8.0 \\
\hline $10^{c}$ & $\operatorname{Al}(\mathrm{OTf})_{3}$ & 1.14 & 1.6 & 0.0 & 0.0 & 0.0 & 0.0 \\
\hline 11 & $\mathrm{CF}_{3} \mathrm{SO}_{3} \mathrm{H}$ & $-3.9 \mathrm{~d}$ & - & 0.0 & 0.0 & 0.0 & 0.0 \\
\hline
\end{tabular}

${ }^{a}$ Reaction conditions: $4 \mathrm{mmol} \mathrm{GLY}, 40 \mathrm{mmol} 30 \%$ aqueous $\mathrm{H}_{2} \mathrm{O}_{2}, 3 \mathrm{~mL} \mathrm{CH}_{3} \mathrm{CN}, 0.10 \mathrm{mmol}$ catalyst, $T=70^{\circ} \mathrm{C}, t=12 \mathrm{~h}$. FA = formic acid; GCA = glycolic acid; $\mathrm{AA}=$ acetic acid. ${ }^{\mathrm{b}} \mathrm{K}_{\mathrm{h}}$ is the hydrolysis constant. For the hydrolysis reaction $x \mathrm{M}^{n+}+y \mathrm{H}_{2} \mathrm{O}=\mathrm{M}_{x}(\mathrm{OH})_{y}(x n-y)++y \mathrm{H}^{+}, \mathrm{p}_{\mathrm{h}} \mathrm{b}^{\mathrm{b}}=-\log K_{a}$, where $K_{a}=$ $\left(\left[\mathrm{M}_{x}(\mathrm{OH})_{y}{ }^{(x n-y)+}\right]\left[\mathrm{H}^{+}\right]^{y}\right) /\left(\left[\mathrm{M}^{n++}\right]^{x+}\left[\alpha_{\mathrm{H} 20}\right]^{y}\right)\left(\left[\mathrm{g}_{x y}\right]\left[\mathrm{gH}^{+}\right]^{y} / \mathrm{g}^{n+}\right), g$ is the ionic activity coefficient and $\alpha_{\mathrm{H} 20}$ is the activity of water. ${ }^{c}$ The reaction was carried out by replacing $\mathrm{H}_{2} \mathrm{O}_{2}$ with $\mathrm{H}_{2} \mathrm{O}$. ${ }^{\mathrm{d}} \mathrm{K}_{\mathrm{a}}$ value. The carbon mass balance for GLY oxidation was more than $85 \%$. $\mathrm{FA}=$ formic acid, GCA = glycolic acid, $\mathrm{AA}=$ acetic acid. 
violently, resulting in the formation of precipitates immediately. This resulted in the low reactivity of $\mathrm{Bi}\left(\mathrm{OTf}_{3}\right.$ [34]. In addition, although $\operatorname{In}(\mathrm{OTf})_{3}$ and $\mathrm{Sc}(\mathrm{OTf})_{3}$ have similar $\mathrm{p} K \mathrm{~h}$ values, the latter showed much higher catalytic activity than the former (Table 1, entries 7 and 8). This suggests that the catalytic activity of metal triflates for GLY oxidation depends not only on their hydrolysis constants $\left(\mathrm{p} K_{\mathrm{h}}\right)$ but also on their water exchange rate constants (WERCs) [35]. The WERC of In(OTf) 3 is three orders of magnitude smaller than that of Sc(OTf) 3 (Table 1) [36]. A smaller WERC value implies a slower dissociation rate of the triflate ligand into $\mathrm{CF}_{3} \mathrm{SO}_{3} \mathrm{H}$. Metal triflates with strong hydrolysis tendency and high ligand dissociation rates show high catalytic activities. Since $\mathrm{CF}_{3} \mathrm{SO}_{3} \mathrm{H}$ alone showed no activity for GLY conversion (Table 1, entry 11), it can be stated that the L (metal cation sites) and B acid species generated by the hydrolysis of $\mathrm{Al}(\mathrm{OTf})_{3}$ during the reaction showed synergism. On the other hand, when the anions of the aluminum salts were replaced (under the same reaction conditions) by $\mathrm{CH}_{3} \mathrm{COO}^{-}, \mathrm{SO}_{4}{ }^{2-}, \mathrm{NO}_{3}{ }^{-}$, or $\mathrm{Cl}^{-}$, the reaction proceeded very sluggishly with a GA yield of only $10 \%-30 \%$ and no FA was formed (Fig. S1, upper). The reactivities of the different $\mathrm{Al}$ salts further confirmed that the anions also played a critical role in GLY conversion, which revealed that the strength of the B acid sites generated by the hydrolysis of the $\mathrm{Al}$ salts was important for this reaction. The $\mathrm{B}$ acid strength of the aluminum salts decreased in the following order: $\mathrm{HCl}\left(\mathrm{p} K_{\mathrm{a}}=-7\right)>\mathrm{CF}_{3} \mathrm{SO}_{3} \mathrm{H}\left(\mathrm{p} K_{\mathrm{a}}=\right.$ $-3.91)>\mathrm{H}_{2} \mathrm{SO}_{4}\left(\mathrm{p} K_{\mathrm{a}}=-3.19\right)>\mathrm{HNO}_{3}\left(\mathrm{p} K_{\mathrm{a}}=-1.4\right)>\mathrm{CH}_{3} \mathrm{COOH}$ $\left(\mathrm{p} K_{\mathrm{a}}=4.79\right)$ [37]. This is roughly consistent with the catalytic performance. Although $\mathrm{HCl}$ showed the strongest acidity, $\mathrm{AlCl}_{3}$ readily hydrolyzed in water, which resulted in the formation of the corresponding mononuclear or polynuclear species [38], and hence a deficiency of $L$ acid sites. This resulted in the loss of activity for GLY conversion.

To investigate the effect of $\mathrm{B}$ and $\mathrm{L}$ acid sites on GLY oxidation, $\mathrm{CF}_{3} \mathrm{SO}_{3} \mathrm{H}$ was added to the different $\mathrm{Al}$ salts $\left(\mathrm{Al}\left(\mathrm{CH}_{3} \mathrm{COO}\right)_{3}\right.$, $\mathrm{Al}_{2}\left(\mathrm{SO}_{4}\right)_{3}, \mathrm{Al}\left(\mathrm{NO}_{3}\right)_{3}$, and $\left.\mathrm{AlCl}_{3}\right)$. Unfortunately, the addition of $\mathrm{CF}_{3} \mathrm{SO}_{3} \mathrm{H}$ did not promote the conversion of GLY significantly, although a small amount of FA was generated in the case of $\mathrm{Al}\left(\mathrm{CH}_{3} \mathrm{COO}\right)_{3}$ and $\mathrm{Al}\left(\mathrm{NO}_{3}\right)_{3}$ (Fig. S1, bottom). Similar tendency was observed when different amounts of $\mathrm{CF}_{3} \mathrm{SO}_{3} \mathrm{H}$ were intro- duced into $\mathrm{Al}(\mathrm{OTf})_{3}$ under the same conditions (Fig. S2). This indicates that besides the acid strength of the catalyst, an optimum $\mathrm{B} / \mathrm{L}$ ratio is also vital for GLY conversion. Hence, $\mathrm{Al}(\mathrm{OTf})_{3}$ with an optimum $\mathrm{B} / \mathrm{L}$ ratio (which enhanced its activity and FA selectivity) was found to be a better catalyst than the other aluminum salts. No significant acceleration was observed in GLY oxidation with the addition of excess $\mathrm{CF}_{3} \mathrm{SO}_{3} \mathrm{H}$ to the $\mathrm{Al}$ salts.

$\mathrm{Al}(\mathrm{OTf})_{3}$ was found to be best catalyst among the metal triflates investigated in this study for GLY conversion. The oxidation of GLY with this catalyst yielded FA, GCA, and a small amount of undetected by-products. The hydrolysis of $\mathrm{Al}(\mathrm{OTf})_{3}$ generated active $\mathrm{L}$ and $\mathrm{B}$ acid species, which enabled the successive reaction steps involved in GLY conversion. $\mathrm{Al}(\mathrm{OTf})_{3}$ was used as the catalyst and the effects of the reaction parameters on its GLY conversion and product distribution were investigated. At the reaction temperatures of $<40{ }^{\circ} \mathrm{C}$, GLY conversion was very poor and only GCA could be detected (Fig. 1a). However, a continuous increase in the reaction temperature up to $70{ }^{\circ} \mathrm{C}$ resulted in accelerated GLY conversion and a rapid increase in the FA yield along with the formation of a small amount of AA and GCA. This indicates that a high reaction temperature is beneficial for the hydrolysis of $\mathrm{Al}(\mathrm{OTf})_{3}$ and generates a large number of reactive sites (B acid sites), which in turn accelerate the formation of FA under the action of hydrogen peroxide. At reaction temperatures higher than $70{ }^{\circ} \mathrm{C}$, hydrogen peroxide undergoes decomposition, which degrades its oxidizing ability [18].

The reaction yielded some by-products, as listed in Table 1 (entry 9). The information of these by-products could be used to elucidate the reaction mechanism of GLY conversion. To further investigate the reaction pathway, the effect of the reaction time on the activity and product yield was investigated (Fig. 1b). From Fig. 1b, it can be observed that at $70^{\circ} \mathrm{C}$, the consumption of GLY proceeded gradually and the FA yield increased significantly with an increase in the reaction time. On the other hand, only a slight increase was observed in the GCA and AA yields with an increase in the reaction time (Fig. 1b). As shown in Fig. S3, the GLY conversion vs. time profile became steeper at high reaction temperatures, and GCA and AA were
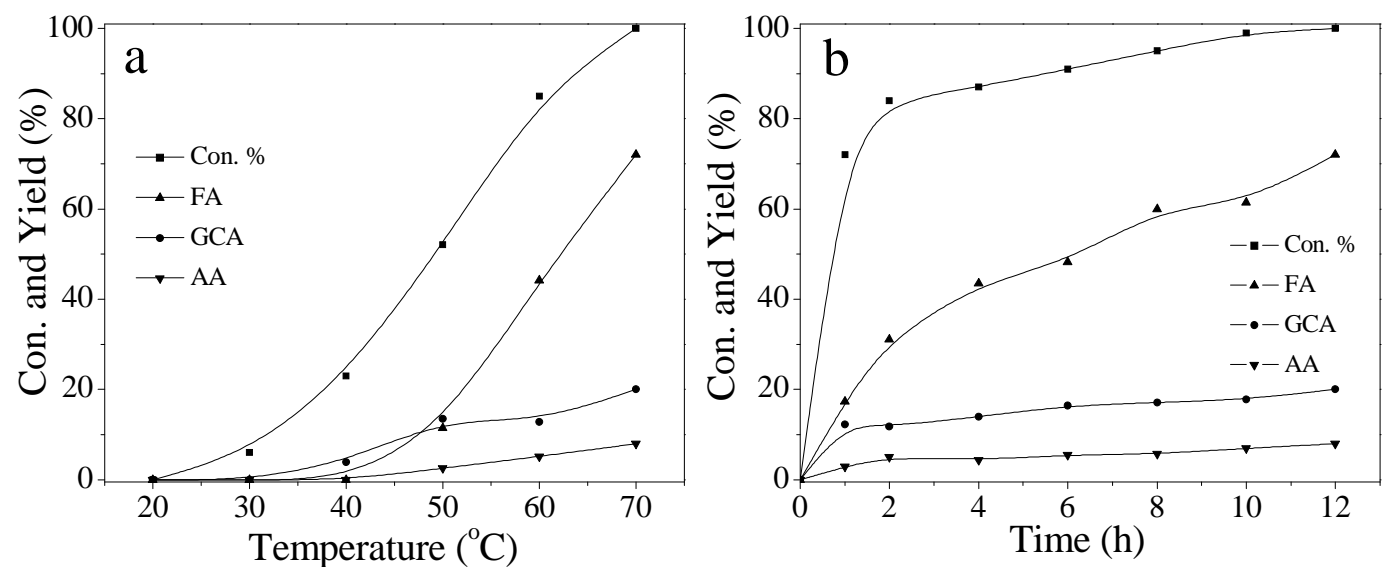

Fig. 1. GLY conversion and product yield at different (a) reaction temperatures and (b) reaction times using the $\mathrm{Al}(\mathrm{OTf})_{3}$ catalyst. Reaction conditions: $4 \mathrm{mmol} \mathrm{GLY,} 40 \mathrm{mmol} 30 \%$ aqueous $\mathrm{H}_{2} \mathrm{O}_{2}, 3 \mathrm{~mL} \mathrm{CH} 3 \mathrm{CN}, 0.10 \mathrm{mmol}$ catalyst. 
the main products at low temperatures. On the basis of the results shown in Figs. 1 and S3, it can be stated that $\mathrm{Al}(\mathrm{OTf})_{3}$ can efficiently activate $\mathrm{H}_{2} \mathrm{O}_{2}$ and GLY at the optimum reaction temperature $\left(70^{\circ} \mathrm{C}\right)$. Moreover, the product evolution of GLY conversion (vs. time) at various temperatures was investigated (Figs. S3b, S3d, S3f, and S3h). It was observed that the GCA yield first increased and then decreased to a negligible level with an increase in the reaction time. AA was detected in very small amounts during the reaction. On the basis of the product distribution, a GLY oxidation reaction route was suggested as follows. GLY first oxidized into some C3 products, which decomposed rapidly and continued to oxidize to FA because of the strong acidity of $\mathrm{Al}(\mathrm{OTf})_{3}$. FA might have been generated from the intermediate product GCA.

The amount of hydrogen peroxide significantly affected GLY oxidation. With an increase in the $\mathrm{H}_{2} \mathrm{O}_{2}$ dosage, a complete GLY conversion was achieved under the given reaction conditions (Fig. 2a). The increase in the $\mathrm{H}_{2} \mathrm{O}_{2}$ dosage significantly affected the product distribution. The FA yield first increased and then decreased with an increase in the $\mathrm{H}_{2} \mathrm{O}_{2}$ dosage. At low hydrogen peroxide concentrations $\left(\mathrm{H}_{2} \mathrm{O}_{2} / \mathrm{GLY} \leq 5\right)$, the reaction proceeded sluggishly and an FA yield of only $40 \%-45 \%$ could be achieved. As the $\mathrm{H}_{2} \mathrm{O}_{2} / \mathrm{GLY}$ molar ratio was increased to 10 , the FA yield increased significantly (up to $72 \%$ ) with complete GLY conversion. However, at $\mathrm{H}_{2} \mathrm{O}_{2} / \mathrm{GLY} \geq 15$, over-oxidation occurred, leading to a decrease in the FA yield. Besides, the reaction was also carried out with different amounts of the substrates (Fig. 2b). It was found that the reaction proceeded smoothly at GLY/catalyst $=40$, yielding $72 \%$ FA, 20\% GCA, and $10 \%$ AA within $12 \mathrm{~h}$. However, at the GLY/catalyst ratios > 40, poor GLY conversion was observed with a low FA yield probably because of the low concentration of the catalytically active sites. On the basis of these observations, it can be stated the combination of $0.1 \mathrm{mmol} \mathrm{Al(OTf})_{3}, 40 \mathrm{mmol} 30 \% \mathrm{H}_{2} \mathrm{O}_{2}$, and $\mathrm{CH}_{3} \mathrm{CN}$ (as the solvent) is ideal for GLY oxidation (4 mmol) at $70{ }^{\circ} \mathrm{C}$ (in order to achieve a good FA yield).

Other biomass platform molecules such as glucose, fructose, ethylene glycol, sorbitol, and 1,3-propanediol were also sub- jected to oxidation and the results are summarized in Table 2. In all the cases, the reaction was carried out in a glass reaction glass flask (25 mL) at $70{ }^{\circ} \mathrm{C}$. Glucose, fructose, ethylene glycol, 1,3-propanediol, and sorbitol showed a moderate-to-high reactivity (Table 2, entries 1-5) on the $\mathrm{Al}(\mathrm{OTf})_{3}$ catalyst, and FA, GCA, and AA were obtained as the main products. Small amounts of glyoxylic acid and isosorbide were detected during the oxidation of fructose and sorbitol, respectively. In addition, 1,3-bihydroxyacetone, lactic acid and GCA were found to be very active substrates towards oxidation. These substrates underwent complete conversion under the given reaction conditions (Table 2, entries 6-8). Both 1,3-bihydroxyacetone and GCA transformed preferentially into FA, while lactic acid transformed into AA. GA converted into FA and GCA with the yields of $57.8 \%$ and $8.1 \%$, respectively (Table 2 , entry 9). This implies that once GA was formed as the intermediate product during GLY oxidation, it further decomposed rapidly into GCA and FA under the given reaction conditions. In addition, CGA further oxidized into FA. AA was found to be a less active substrate. This is consistent with the kinetic observations (Figs. 1 and S3).

Catalyst recyclability is crucial for GLY conversion. Although the reaction system used in this study remained in a homogeneous phase during the reaction, the $\mathrm{Al}(\mathrm{OTf})_{3}$ catalyst could also be recovered by distillation. In order to ensure the clean extraction of the product after the reaction, the reaction was carried out with only $\mathrm{H}_{2} \mathrm{O}$ as the solvent. The FA yield obtained during the first scan in this case was slightly lower (Fig. 3) than that obtained when $\mathrm{CH}_{3} \mathrm{CN}$ was used as the solvent (Table 1, entry 9), and the catalyst could be employed for the next run. It was found that when $\mathrm{H}_{2} \mathrm{O}$ alone was used as the solvent, $\mathrm{Al}(\mathrm{OTf})_{3}$ could be reused for at least five times with high conversion. However, a slight decrease was observed in the FA yield. This can be attributed to the loss of $\mathrm{B}$ acid sites $\left(\mathrm{CF}_{3} \mathrm{SO}_{3} \mathrm{H}\right)$ during the course of catalyst recycling. When an optimum amount of $\mathrm{CF}_{3} \mathrm{SO}_{3} \mathrm{H}$ was added prior to the seventh run, an $\mathrm{FA}$ yield same as that obtained during the first run was obtained, which resulted in catalyst deactivation (Fig. 3). However, at low reaction times, the presence of excess GLY during the course of
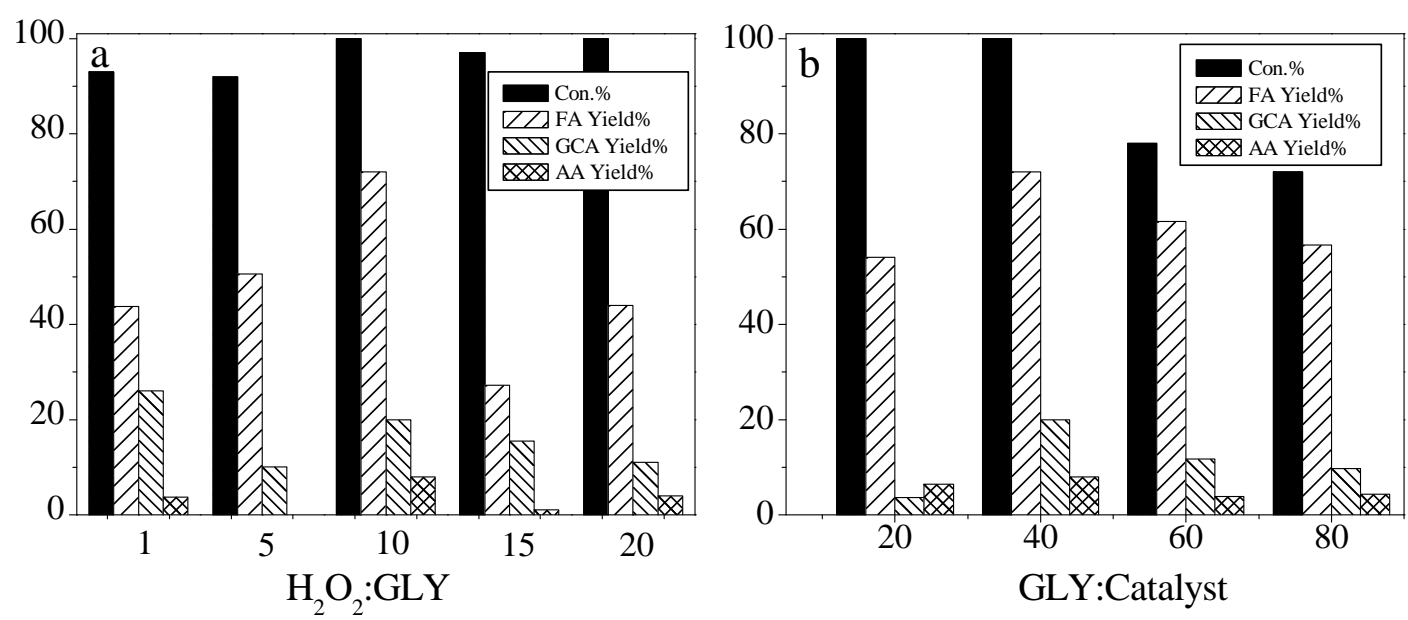

Fig. 2. Effect of the amounts of $\mathrm{H}_{2} \mathrm{O}_{2}$ and $\mathrm{GLY}$ on the performance of the catalyst. Reaction conditions: (a) $0.10 \mathrm{mmol} \mathrm{Al}(\mathrm{OTf})_{3}, 4 \mathrm{mmol} \mathrm{GLY}, 30 \%$ aqueous $\mathrm{H}_{2} \mathrm{O}_{2}, 3 \mathrm{~mL} \mathrm{CH} 3 \mathrm{CN}, \mathrm{T}=70^{\circ} \mathrm{C}, \mathrm{t}=12 \mathrm{~h}$; (b) $0.10 \mathrm{mmol} \mathrm{Al}(\mathrm{OTf})_{3}, 40 \mathrm{mmol} 30 \%$ aqueous $\mathrm{H}_{2} \mathrm{O}_{2}, 3 \mathrm{~mL} \mathrm{CH}_{3} \mathrm{CN}, \mathrm{T}=70{ }^{\circ} \mathrm{C}, t=12 \mathrm{~h} . \mathrm{H}_{2} \mathrm{O}_{2}: \mathrm{GLY}$ and GLY:catalyst denote the molar ratios. 
Table 2

Oxidation of various biomass platform molecules with the $\mathrm{Al}(\mathrm{OTf})_{3}$ catalyst.

\begin{tabular}{lccrrrrrr}
\hline \multirow{2}{*}{ Entry } & \multirow{2}{*}{ Substrate } & Conversion (\%) & \multicolumn{5}{c}{ Yield (\%) } \\
\cline { 4 - 8 } & & & FA & GCA & AA & GLA & IS & Others \\
\hline 1 & Glucose & 85.0 & 6.8 & 15.3 & 0.0 & - & - & 77.9 \\
2 & Fructose & 100.0 & 17.6 & 14.5 & 8.7 & 5.4 & - & 53.8 \\
3 & Ethylene glycol & 100.0 & 60.8 & 9.4 & 0.0 & - & - & 29.8 \\
4 & 1,3-Propanediol & 60.0 & 16.8 & 4.2 & 27.6 & - & - & 51.4 \\
5 & Sorbitol & 54.0 & 13.2 & 0.0 & 0.0 & - & 18.9 & 67.9 \\
6 & 1,3-Dihydroxy-acetone & 100.0 & 37.0 & 0.0 & 9.0 & - & - & 54.0 \\
7 & Lactic acid & 100.0 & 7.0 & 3.0 & 41.0 & - & - & 49.0 \\
8 & GCA & 97.0 & 63.1 & 0.0 & 0.0 & - & - & 36.9 \\
9 & GA & 80.6 & 57.8 & 8.1 & 0.0 & - & - & 34.1 \\
10 & AA & 12.1 & 12.1 & 0.0 & 0.0 & - & - & 87.9 \\
\hline
\end{tabular}

Reaction conditions: $4 \mathrm{mmol}$ substrate, $40 \mathrm{mmol} 30 \%$ aqueous $\mathrm{H}_{2} \mathrm{O}_{2}, 0.10 \mathrm{mmol}$ catalyst, $3 \mathrm{~mL} \mathrm{CH} \mathrm{CN}_{3} T=70{ }^{\circ} \mathrm{C}, t=12 \mathrm{~h}$. FA $=$ formic acid; $\mathrm{GCA}=$ glycolic acid; GA = glyceric acid; AA = acetic acid; IS = isosorbide; LA = lactic acid; GLA = glyoxylic acid. The other products consisted of some unknown polymers and $\mathrm{CO}_{2}$.

catalyst recycling resulted in a severe catalyst deactivation because of the generation of an oily brownish residue because of GLY polymerization (Fig. S4). The substrate molecules could not access the $\mathrm{Al}(\mathrm{OTf})_{3}$ catalyst because of the blockage of the active sites by impurities or side products, resulting in a decrease in the catalytic activity [39]. The spent $\mathrm{Al}(\mathrm{OTf})_{3}$ catalyst was subjected to FT-IR characterization. The absorption bands at 1252 and $1031 \mathrm{~cm}^{-1}$ correspond to $v(\mathrm{~S}=0)$ and the band at $1179 \mathrm{~cm}^{-1}$ corresponds to $v(\mathrm{C}-\mathrm{F})$ (Figs. S5a and S5b). However, the intensity of these bands decreased slightly after four recycles (Fig. S5c). In addition, the ICP analysis results also showed that the molar ratios of $\mathrm{S}$ and $\mathrm{Al}$ decreased from 3.0 to 2.0 after four recycles. These results indicate that $\mathrm{CF}_{3} \mathrm{SO}_{3} \mathrm{H}$ could leach into the effluent (the $\mathrm{CH}_{2} \mathrm{Cl}_{2}$ phase) during the consecutive runs, resulting in a decrease in the FA yield, as shown in Fig. 3.

When hydrogen peroxide is used as a reactive oxygen donor, the oxidation reaction proceeds via two pathways: (1) the generation of highly reactive free hydroxyl radicals $(\bullet \mathrm{OH})$ and (2) the formation of a metal peroxide species, which then catalyzes the reaction $[40,41]$. To investigate the possible radical

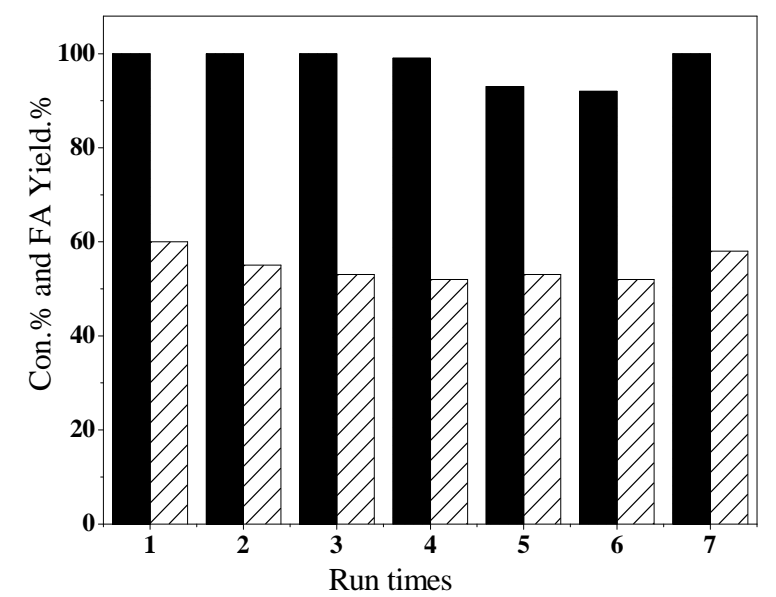

Fig. 3. Catalytic recycling of $\mathrm{Al}(\mathrm{OTf})_{3}$. Reaction conditions: $4 \mathrm{mmol} \mathrm{GLY}$, $40 \mathrm{mmol} 30 \%$ aqueous $\mathrm{H}_{2} \mathrm{O}_{2}, 0.10$ mmol catalyst, without $\mathrm{CH}_{3} \mathrm{CN}, T=70$ ${ }^{\circ} \mathrm{C}, t=12 \mathrm{~h} . \mathrm{CF}_{3} \mathrm{SO}_{3} \mathrm{H}(0.30 \mathrm{mmol})$ was added to the reaction mixture prior to the reaction for run 7 . mechanism, BHT, which is a strong radical inhibitor, was employed in the reaction and its effect on the activity of the catalyst was investigated [42,43]. The GLY conversion vs. time curves of $\mathrm{Al}(\mathrm{OTf})_{3}$ are shown in Fig. 4. It can be observed that after the addition of BHT, no significant change was observed in the GLY conversion/time profile of $\mathrm{Al}(\mathrm{OTf})_{3}$ unlike the case when BHT was used as the additive. This suggests that a radical intermediate was not involved in this oxidation reaction.

Because Al(OTf) 3 can act as a strong L acid site during GLY conversion, it was assumed that the aluminum cation preferentially coordinated with the hydroxyl group. ${ }^{1} \mathrm{H}$ NMR examinations can detect complex formation and have been used to investigate the complexation between metal sites and inactivated alcohols $[44,45]$. Thus, we carried out ${ }^{1} \mathrm{H}$ NMR studies on the complexation of $\mathrm{Al}(\mathrm{OTf})_{3}$ to GLY to determine whether the aluminum cation coordinated with both the hydroxyl oxygen atoms. As shown in Fig. 5, the hydroxyl signal (H1) of GLY broadened significantly after the addition of the $\mathrm{Al}(\mathrm{OTf})_{3}$ catalyst, and the chemical shift of the $\mathrm{H} 2-\mathrm{H} 4$ protons also moved to the low field region as compared to that in the case of pure GLY.

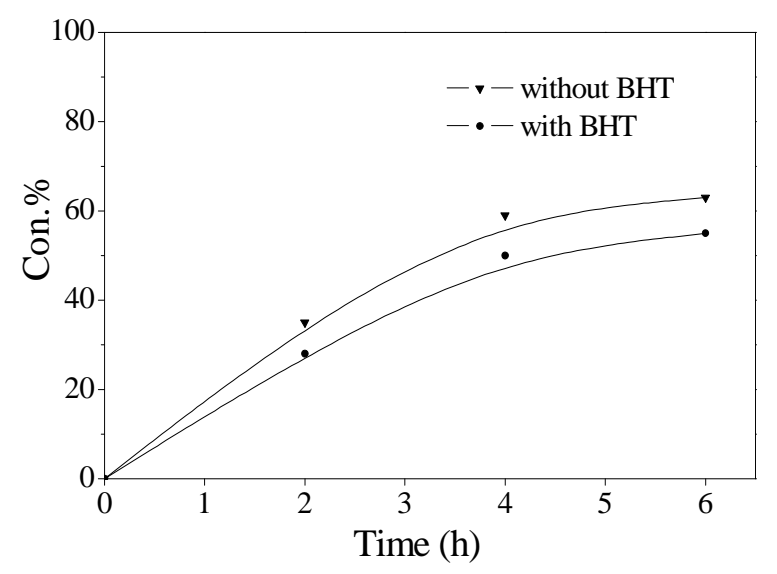

Fig. 4. Time profile of GLY oxidation catalyzed by $\mathrm{Al}(\mathrm{OTf})_{3}$ with and without BHT. Reaction conditions: $4 \mathrm{mmol}$ GLY, $10 \mathrm{mmol} 30 \%$ aqueous $\mathrm{H}_{2} \mathrm{O}_{2}, 10 \mathrm{~mL} \mathrm{CH}{ }_{3} \mathrm{CN}, 0.10 \mathrm{mmol}$ catalyst, $T=70{ }^{\circ} \mathrm{C} .0 .80 \mathrm{mmol}$ BHT was added for the reaction. 


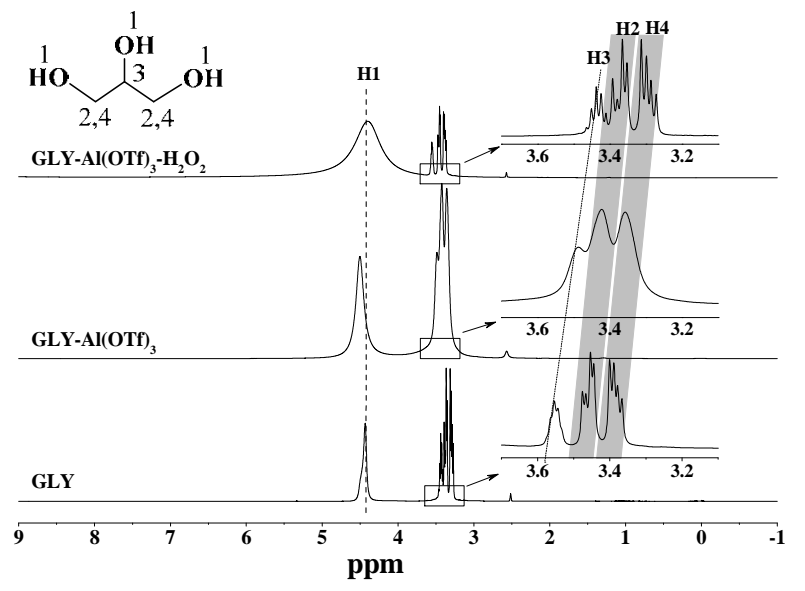

Fig. 5. Interaction between GLY and the catalyst, as reflected by the ${ }^{1} \mathrm{H}$ NMR spectra in $\mathrm{d}_{6}$-DMSO. $0.9 \mathrm{mmol}$ of GLY, $4.5 \mathrm{mmol} 30 \%$ aqueous $\mathrm{H}_{2} \mathrm{O}_{2}, 0.03 \mathrm{mmol}$ catalyst, $0.5 \mathrm{~mL} \mathrm{~d}_{6}$-DMSO. The samples were stirred vigorously prior to the NMR measurements at room temperature.

Moreover, the hydroxyl signal peak of the $\mathrm{H} 1$ proton showed significant broadening because of the addition of $\mathrm{H}_{2} \mathrm{O}_{2}$ and the signals from the $\mathrm{H} 2-\mathrm{H} 4$ protons showed a high tendency to move towards the low field region. These results suggest that the interaction of $\mathrm{Al}(\mathrm{OTf})_{3}$ with GLY occurred most likely through a preferential complexation of $\mathrm{Al}(\mathrm{OTf})_{3}$ to the three hydroxyl oxygen atoms of GLY. Furthermore, the addition of $\mathrm{H}_{2} \mathrm{O}_{2}$ to $\mathrm{Al}(\mathrm{OTf})_{3}$ produced new species, leading to a stronger interaction between the $\mathrm{Al}$ sites and GLY.

To identify the intermediate products formed during GLY oxidation $1 \mathrm{H}$ NMR spectroscopy was used. Thus, the reaction was carried out in $\mathrm{d}_{6}$-DMSO prior to the ${ }^{1} \mathrm{H}$ NMR analysis. The concentration of GLY in d6-DMSO was increased in order to clearly observe the $1 \mathrm{H}$ NMR signals of the products. As shown in Fig 6, after $2 \mathrm{~h}$ of the reaction, the signals corresponding to FA (H5), GCA (H6), AA (H7) were observed, while the signals corresponding to the (H2-H4) protons of GLY almost disappeared even at a relatively high concentration as compared to that used in Fig. 5. This is consistent with the results shown in Fig. 1(b). This indicates that after $2 \mathrm{~h}$, most of the GLY was consumed in the reaction. With an increase in the reaction time, the intensity of the proton signal of FA (H5) increased. This suggests that GLY oxidation is subjected to a series of successive steps, and GCA and AA can be the intermediate species. It should be noted that the intensity of the proton signals of GCA (H6) and AA (H7) remained unchanged probably because of the low concentrations of the intermediate species. These results are consistent with the kinetic observations discussion earlier (Fig. S3).

Since a trace of GA was detected during the initial reaction stage, it can be stated that GLY was transformed into GA during the first step and further decomposed rapidly into GCA and FA under the effect of the catalyst. GCA in turn oxidized to FA after the addition of hydrogen peroxide. A possible reaction pathway is shown in Scheme 1.

On the basis of the results discussed thus far, the free radical mechanism could be excluded. The activity test results showed

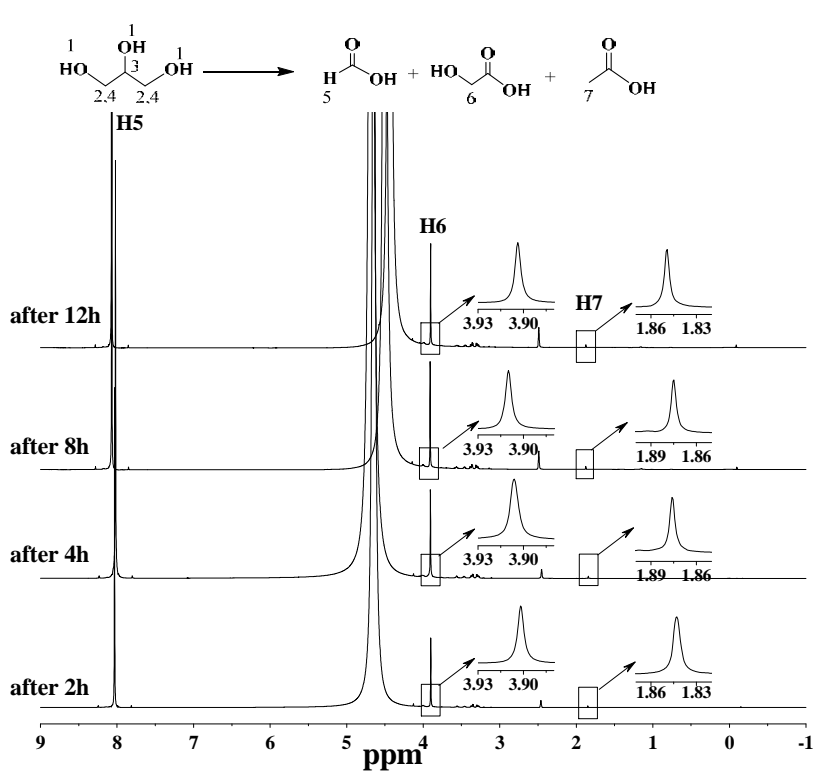

Fig. 6. ${ }^{1} \mathrm{H}$ NMR spectra of $\mathrm{GLY}-\mathrm{Al}(\mathrm{OTf})_{3}-\mathrm{H}_{2} \mathrm{O}_{2}$ at various reaction times. The reaction was carried out at $70{ }^{\circ} \mathrm{C}$ prior to the NMR measurements. Reaction conditions: $1.5 \mathrm{mmol} \mathrm{GLY}, 7.5 \mathrm{mmol} 30 \%$ aqueous $\mathrm{H}_{2} \mathrm{O}_{2}, 0.05$ mmol catalyst, $0.5 \mathrm{~mL} \mathrm{~d}_{6}$-DMSO.

that $\mathrm{Al}(\mathrm{OTf})_{3}$ alone cannot activate GLY to trigger its conversion. As can be observed from Table 1, the introduction of $\mathrm{H}_{2} \mathrm{O}_{2}$ not only played a vital role in accelerating GLY conversion, but also promoted the oxidation of GLY to FA. Although the mechanism behind the reaction of GLY with $\mathrm{Al}(\mathrm{OTf})_{3}$ is still unclear, the formation of $\mathrm{Al}-\mathrm{O}, \mathrm{Al}$-peroxo, or Al-hydroperoxide species is highly possible [25,46-48], which could be responsible for GLY conversion and the chemoselectivity of the reaction.

\section{Conclusions}

In this study, we used metal(III) triflates to catalyze GLY oxidation. It was found that $\mathrm{Al}(\mathrm{OTf})_{3}$ exhibited excellent catalytic activity and selectivity towards the oxidation of GLY to FA. The use of $\mathrm{H}_{2} \mathrm{O}_{2}$ as the oxidant under mild reaction conditions resulted in a complete GLY conversion and an FA yield of up to $72 \%$ was obtained. The apparent synergism between the $\mathrm{L}$ acid sites and the in-situ generated B acid species of the metal triflates was found to improve their catalytic activity and FA yield. Furthermore, it was found that the catalytic activity of metal triflates is significantly affected by both their acid strength and

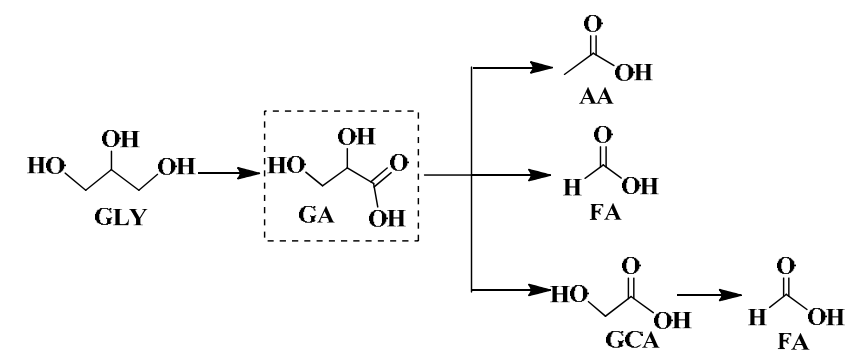

Scheme 1. Proposed reaction pathway for GLY oxidation to FA. 


\section{Graphical Abstract}

Chin. J. Catal., 2019, 40: 534-542 doi: S1872-2067(19)63319-X

\section{Aluminum(III) triflate-catalyzed selective oxidation of glycerol to formic acid with hydrogen peroxide}

Kang Kong, Difan Li, Wenbao Ma, Qingqing Zhou, Guoping Tang, Zhenshan $\mathrm{Hou}^{*}$

East China University of Science and Technology

Commercially available aluminum(III) triflate was used as a cost-effective catalyst for the selective oxidation of glycerol to formic acid under mild reaction conditions.

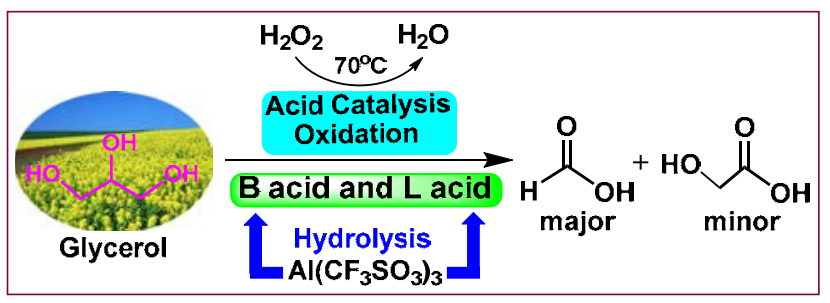

[19] M. Tao, D. Zhang, X. Deng, X. Li, J. Shi, X. Wang, Chem. Commun., 2016, 52, 3332-3335.

[20] Z. Wang, L. Wang, Y. Jiang, M. Hunger, J. Huang, ACS Catal., 2014, 4, 1144-1147.

[21] P. P. Pescarmona, K. P. F. Janssen, C. Delaet, C. Stroobants, K. Houthoofd, A. Philippaerts, C. De Jonghe, J. S. Paul, P. A. Jacobs, B. F. Sels, Green Chem., 2010, 12, 1083-1089.

[22] K. M. A. Santos, E. M. Albuquerque, L. E. P. Borges, M. A. Fraga, Mol. Catal., 2018, 458, 198-205.

[23] D. Schinzer, Selectivities in Lewis Acid Promoted Reactions, Kluwer Academic Publishers, Dordrecht, 1989.

[24] S. Kobayashi, Eur. J. Org. Chem., 1999, 15-27.

[25] B. R. Raju, S. Sarkar, U. C. Reddy, A. K. Saikia, J. Mol. Catal. A, 2009, 308, 169-173.

[26] K. Tominaga, A. Mori, Y. Fukushima, S. Shimada, K. Sato, Green Chem., 2011, 13, 810-812.

[27] T. Ohshima, J. Ipposhi, Y. Nakahara, R. Shibuya, K. Mashimab, Adv. Synth. Catal., 2012, 354, 2447-2452.

[28] G. Compain, L. Sikk, L. Massi, J. F. Gal, E. Dunach, ChemPhysChem, 2017, 18, 683-691.

[29] C. Crotti, E. Farnetti, J. Mol. Catal. A, 2015, 396, 353-359.

[30] M. Yuan, D. Li, X. Zhao, W. Ma, K. Kong, W. Ni, Q. Gu, Z. Hou, Acta Phys. Chim. Sin., 2018, 34, 886-895.

[31] S. Kobayashi, S. Nagayama, T. Busujima, J. Am. Chem. Soc., 1998, 120, 8287-8288.

[32] S. Kobayashi, K. Manabe, Acc. Chem. Res., 2002, 35, 209-217.

[33] S. Kobayashi, C. Ogawa, Chem. Eur. J., 2006, 12, 5954-5960.

[34] P. Ondet, G. Lemiere, E. Dunach, Eur. J. Org. Chem., 2017, 761-780.

[35] Y. Wang, F. Vogelgsang, Y. Roman-Leshkov, ChemCatChem, 2015, 7, 916-920.

[36] Y. Koito, K. Nakajima, H. Kobayashi, R. Hasegawa, M. Kitano, M. Hara, Chem. Eur. J., 2014, 20, 8068-8075.

[37] D. R. Lide, CRC Handbook of Chemistry and Physics, CRC, 2005, 1274-1286.

[38] C. F. Baes Jr., R. E. Mesmer, The Hydrolysis of Cations, John Wiely and Sons, New York, 1976, 1-459.

[39] M. Besson, P. Gallezot, Catal. Today, 2000, 57, 127-141.

[40] B. Kakavandi, A. A. Babaei, RSC Adv., 2016, 6, 84999-85011.

[41] S. Zhang, X. Zhao, H. Niu, Y. Shi, Y. Cai, G. Jiang, J. Hazard. Mater., 2009, 167, 560-566.

[42] N. I. Moiseeva, A. E. Gekhman, V. V. Minin, G. M. Larin, M. E. Bashtanov, A. A. Krasnovskii, I. I. Moiseev, Kinet. Catal., 2000, 41, 170-182.

[43] M. J. L. Tschan, C. M. Thomas, H. Strub, J. F. Carpentier, Adv. Synth. 
Catal., 2009, 351, 2496-2504.

[44] L. Coulombel, M. Rajzmann, J. M. Pons, S. Olivero, E. Dunach, Chem. Eur. J., 2006, 12, 6356-6365.

[45] V. V. Konshin, B. N. Chernyshov, J. Struct. Chem., 1984, 24, 635-637.
[46] J. J. Wang, A. X. Zhou, G. W. Wang, S. D. Yang, Adv. Synth. Catal., 2014, 356, 3356-3362.

[47] D. Mandelli, A. C. N. do Amaral, Y. N. Kozlov, L. S. Shulpin, A. J. Bonon, W. A. Carvalho, G. B. Shulpin, Catal. Lett., 2009, 132, 235-243.

[48] C. R. Goldsmith, Coordin. Chem. Rev., 2018, 377, 209-224.

\title{
$\mathrm{Al}\left(\mathrm{CF}_{3} \mathrm{SO}_{3}\right)_{3}$ 催化选择性氧化甘油转化为甲酸 \\ 孔康, 李迪帆, 马文保, 周青青, 唐国平, 侯震山* 华东理工大学化学与分子工程学院, 工业催化研究所, 先进材料重点实验室, 上海200237
}

\begin{abstract}
摘要: 化石能源的日渐紧缺以及在使用过程中带来的环境污染引起了世界范围内学术界和工业界的密切关注, 而生物柴油 作为一种环境友好的可再生资源, 可以替代化石能源, 具有非常好的发展前景. 虽然生物柴油生产过程中会产生大量甘油 副产物, 但是甘油也是一种重要的生物质平台分子, 可用于生产多种高附加值的化学品. 为了提高甘油的利用价值, 同时 探索一条高产率制备甲酸的可替代路径, 本文研究了一个在较温和条件下, 以三氟甲磺酸盐为催化剂, 过氧化氢为氧化剂, 将甘油选择性氧化为甲酸和乙醇酸的催化体系. 结果表明, 金属阳离子的催化活性与它们的水解常数 $\left(K_{\mathrm{h}}\right)$ 和内含水配体取 代的交换速率常数(水交换速率常数, WERC)之间存在密切的相关性, 适当的水解常数和较高的水交换速率常数有利于甘 油氧化反应. 在考察的多种金属三氟甲磺酸盐中, 三氟甲磺酸铝(III)是甘油选择性氧化为甲酸最有效的催化剂. 在温度为 $70{ }^{\circ} \mathrm{C}$, 反应 $12 \mathrm{~h}$ 的条件下, 甲酸收率可达 $72 \%$. 另外, 反应体系中甘油、催化剂和 $\mathrm{H}_{2} \mathrm{O}_{2}$ 的比例对甘油氧化产物分布有一定影 响. 一系列实验研究表明, 催化体系中产生的Lewis酸和Brønsted酸存在协同作用, 具有适当Lewis酸和Brønsted酸比例的金 属盐呈现出良好的催化性能, 催化剂过度水解可降低其催化活性. $\mathrm{Al}(\mathrm{OTf})_{3}$ 原位水解过程中产生的Lewis酸性物种 $\left[\mathrm{Al}(\mathrm{OH})_{\mathrm{x}}\right]^{n+}$ 和Brønsted酸物种 $\mathrm{CF}_{3} \mathrm{SO}_{3} \mathrm{H}$ 是催化甘油转化的活性中心, 另外在 $\mathrm{H}_{2} \mathrm{O}_{2}$ 存在下产生的 $\mathrm{Al}$ 过氧物种可能是甘油氧化 的活性中心. 反应动力学和 ${ }^{1} \mathrm{H} N \mathrm{~N}$ R 研究表明, 在甘油转化为甲酸的过程中, 甘油酸、乙醇酸和乙酸可能是反应的中间产物, 可以继续氧化转化为甲酸. 该催化剂体系同样适用于其他生物平台分子选择性氧化转化为有机羧酸, 并且能够在甘油氧 化反应中多次循环使用. $\mathrm{Al}(\mathrm{OTf})_{3}$ 作为简单易得的催化剂具有高效的催化性能和优异的循环使用性能, 这将为甘油选择性 氧化转化为高附加值产品开辟一种新的方法.
\end{abstract}

关键词: $\mathrm{Al}(\mathrm{OTf})_{3}$; 甘油; 过氧化氢; 选择性氧化; 甲酸

收稿日期: 2018-11-10. 接受日期: 2019-01-25. 出版日期: 2019-04-05.

*通讯联系人. 电话/传真: (021)64251686; 电子信箱: houzhenshan@ecust.edu.cn

基金来源：国家自然科学基金(21773061, 21373082); 上海市教委科研创新项目(15ZZ031).

本文的电子版全文由Elsevier出版社在ScienceDirect上出版(http://www.sciencedirect.com/science/journal/18722067). 